\title{
Insight towards Nucleation Mechanism and Change in Morphology for Nanostructured Platinum Thin Film Directly Grown on Carbon Substrate via Electrochemical Deposition
}

\author{
Prabhakaran Dhanasekaran ${ }^{1, *}$, Swaminathan Rajavarman ${ }^{2}$, Sivasuriyanarayanan Vinod Selvaganesh ${ }^{3}$ and \\ Santoshkumar Dattatray Bhat ${ }^{1, *}$ \\ 1 CSIR-Central Electrochemical Research Institute (CECRI), CSIR-Madras Complex, Tamil Nadu 600113, India \\ 2 Centre for Nanoscience and Nanotechnology, University of Madras, Tamil Nadu 600085, India; \\ srajavarman11@gmail.com \\ 3 Indian Institute of Technology, Madras, Chennai, Tamil Nadu 600036, India; svsganesh.dr@gmail.com \\ * Correspondence: dhanascient@gmail.com (P.D.); sdbhat@cecri.res.in (S.D.B.); \\ Tel./Fax: +91-44-22542456 (S.D.B.)
}

\section{check for}

updates

Citation: Dhanasekaran, P.;

Rajavarman, S.; Selvaganesh, S.V.;

Bhat, S.D. Insight towards Nucleation

Mechanism and Change in

Morphology for Nanostructured

Platinum Thin Film Directly Grown on Carbon Substrate via

Electrochemical Deposition. Materials

2021, 14, 2330. https://doi.org/

$10.3390 /$ ma14092330

Academic Editor: Rolando Pedicini

Received: 30 March 2021

Accepted: 26 April 2021

Published: 30 April 2021

Publisher's Note: MDPI stays neutral with regard to jurisdictional claims in published maps and institutional affiliations.

Copyright: (c) 2021 by the authors. Licensee MDPI, Basel, Switzerland. This article is an open access article distributed under the terms and conditions of the Creative Commons Attribution (CC BY) license (https:// creativecommons.org/licenses/by/ $4.0 /)$.

\begin{abstract}
Nanocrystalline platinum with different morphologies is synthesized via electrochemical deposition technique. The nucleation mechanism and its structural effect over the electrodeposited $\mathrm{Pt}$ on carbon electrodes have been systematically studied. Powder X-ray diffraction, $\mathrm{X}$-ray photoelectron spectroscopy, and field-emission scanning electron microscopy are employed to study nucleation, oxidation states, and Pt structure growth on a carbon electrode. This study reports significant development of $\mathrm{Pt}$ metal nanoparticles with different morphologies such as a sphere, flower, coreflower, and rod-like structure directly fabricated on carbon electrode while tuning the deposition parameters such as current density, time, temperature, $\mathrm{pH}$ during the deposition process. The proposed electrochemical route represents a superior fabrication procedure for large-scale electrode fabrication compared to a conventional method for preparing membrane electrode assemblies for fuel cell stacks.
\end{abstract}

Keywords: different morphology; electrochemical deposition; fuel cell; durability; PEFC

\section{Introduction}

Fabrication and surface engineering of platinum metal nanoparticles with different morphology and crystal-face has been the focus of many recent studies due to the broad class and most promising applications such as polymer electrolyte fuel cell [1,2], industrial synthesis of ammonia [3], electrochemical oxidation of ethanol and methanol [4-6], glucose detection [7], carbon monoxide gas sensors [8], petroleum refining [9], hydrogen production and anticancer drugs $[10,11]$. The preparation of metal particles with well-controlled size and shapes are more important for catalytic applications. For various catalytic applications, the rate per unit of the surface area of metal is customarily dependent on the crystalline size, morphology, and then crystalline plane orientation generally referred to as structure-sensitive responses [12]. In the past decade, various wet chemical processes, such as hydrothermal, sol-gel, microwave, polyol, colloidal, sodium borohydride reduction, impregnation, etc., have been employed for synthesizing nanocrystalline as well as polycrystalline metal nanoparticles [13-15].

In the current scenario, these methods have also offered control over the morphology and particle size while varying different organic polymer surfactants and reducing agents. In the last decade, platinum metal nanoparticles appear to be one of the most efficient catalysts for various applications. There are fewer reports available to synthesize controlled-size and shapes of nanoparticles using adequate polymers [16]. Ramirez et al. reported that various shaped Pt nanostructures such as dendrites or nanowires and isolated nanoparticles were obtained using Tris(dibenzylideneacetone) diplatinum used as a 
precursor [17]. Similarly, our previous work also reported that Pt metal nanoparticle with a size of 3-5 $\mathrm{nm}$ was realized by a simple ethylene glycol reduction method [18].

Although a wide diversity of methodologies to prepare Pt metal particles has been explored, methods that can preserve the shape and size of Pt metal in similar materials have been scanty. In view of this, in the present study, different Pt metal particle morphology is explored via electrochemical deposition. Besides, through the electrochemical deposition technique, one can control the purity, crystallinity, particle size, and nucleation, as well as deposition amount and surface morphology, while altering various deposition parameters. In a typical electrochemical deposition process, metal ion precursors are electrochemically reduced to their metallic state by direct electron transfer from the working electrode [19-21].

Liu et al. prepared a cubic-shaped Pt nanoparticle by a one-step electrochemical method with the formulated electrolyte of chloroplatinic acid and hydrochloric acid [22]. Y. Song et al. reported that Pd dendritic nanowires were directly deposited onto ITO glass with the optimum electrolyte of $\mathrm{H}_{3} \mathrm{BO}_{3}$ and $\mathrm{PdSO}_{4}$ at room temperature [23]. Jia et al. prepared uniform nanoplates and nano-trees of $\mathrm{Pd}$ through electrodeposition on a gold substrate by a template-free method [24]. Similarly, Takai et al. obtained a Pt film with three different mesostructures, such as two-dimensional-hexagonal, cage-type, and globular shape synthesized by adjusting the composition ratio between block co-polymer (polystyrene-b-polyethene oxide) and Pt ion precursor solutions [25]. Moreover, many capping agents are introduced, which results in the formation of heterogeneous impurities and requires post-treatment to remove them considering the chemical preparation route. However, in the case of electrochemical deposition of $\mathrm{Pt}$, the metal nanoparticles could be directly grown on a conductive substrate or the electrode for various electrochemical applications.

One-step synthesis of Pt nanoparticles of various morphologies via electrochemical deposition was performed on a conductive carbon substrate in the present study. The overall synthesis process is simple, wherein only chloroplatinic acid, citric acid, and sulfuric acid are required. As far as we are aware, this is the first-ever report on the simultaneous direct fabrication of sphere, flower-, and core-flower-shaped Pt metal with (111) facets orientation on a larger active area substrate of $35 \mathrm{~cm}^{2}$ by electrochemical deposition. Also, the effect of temperature, time, and $\mathrm{pH}$ have been significantly explored. The present work addresses both morphologies as well as facets of orientation. The successful formation of Pt metal nanosphere, flower, core-flower, and rod fenced with (111) planes are confirmed by field emission scanning electron microscopy (FE-SEM), powder X-ray diffraction (XRD), and high-resolution transmission electron microscopy (HR-TEM). Its application in fuel cells as the electrode is also studied. Scheme 1 illustrates Pt metal nanostructure directly deposited on carbon substrate using one-step electrochemical deposition technique and its expected surface morphology while varying current density, time, temperature, and $\mathrm{pH}$. 


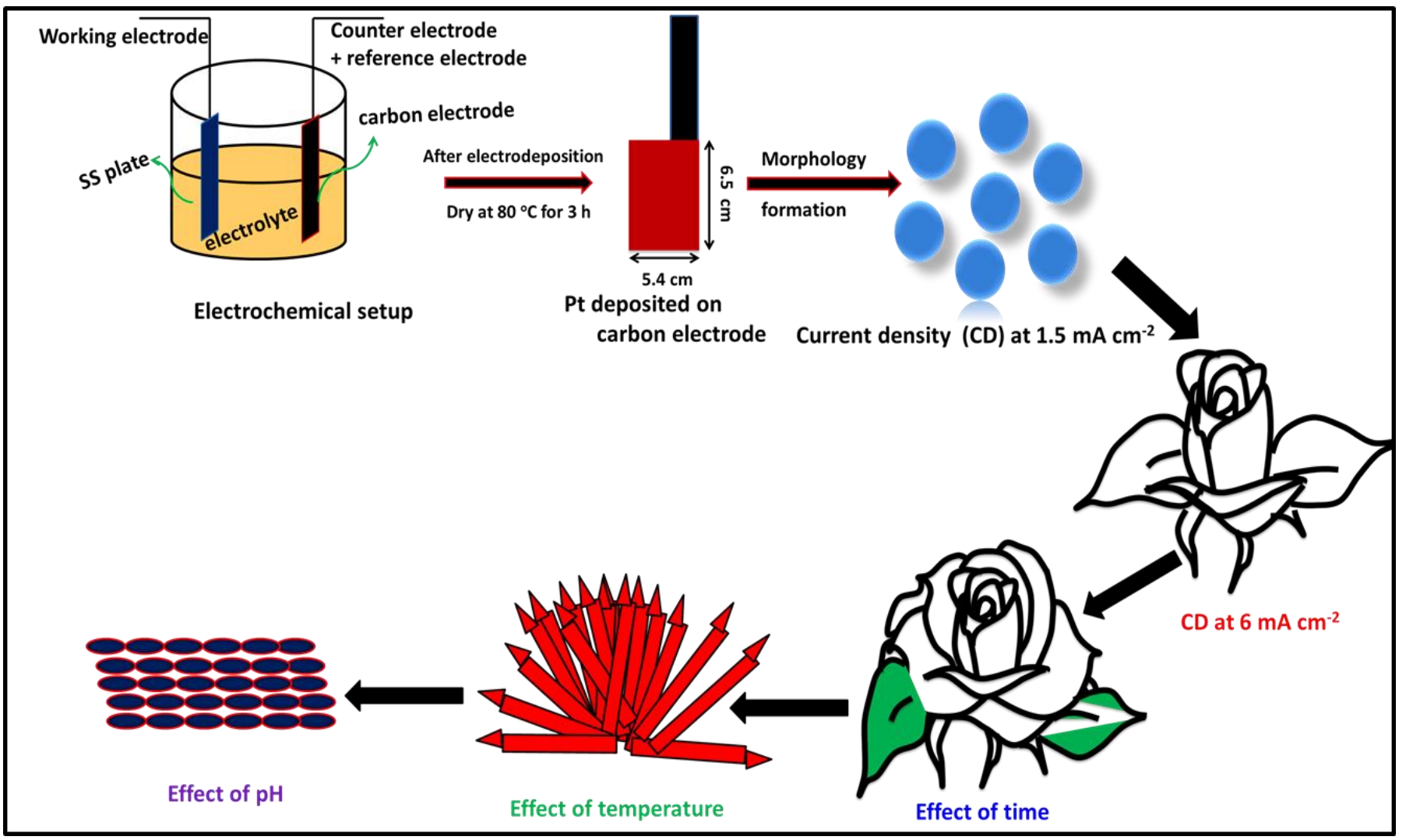

Scheme 1. Schematic diagram of electrochemical two electrode systems and formulated electrolyte with exposed conductive carbon substrate $(5.4 \mathrm{~cm} \times 6.5 \mathrm{~cm})$ and proposed Pt morphology.

\section{Experimental Section}

\subsection{Electrodeposition of Pt Metal Nanoparticles}

An electrochemical workstation system (Autolab PGSTAT-30, Ecochemie-Metrohm, The Netherlands) was used for the experiments, wherein the Pt metal nanoparticles were electrodeposited on a carbon substrate. Stainless steel $(316 \mathrm{~L})$ with an active area of $80 \mathrm{~cm}^{2}$ was used as a working electrode, and a carbon paper (commercial DC-35 SIGRACET ${ }^{\circledR}$ Fuel Cell components (Wiesbaden, Germany) with a thickness of $0.300 \mathrm{~mm}$ and an active area of $35 \mathrm{~cm}^{2}$ ) acted as a counter electrode for electrodeposition experiments. During the experiment, the rest of the carbon paper and backside of the active area was covered with Teflon tape. In the present work, the reference electrode was inter-connected with the counter electrode to form a two-electrode system. Before the electrodeposition process, both electrodes were separately immersed in diluted $\mathrm{HCl}$ for $5 \mathrm{~min}$, followed by frequent rinsing with adequate distilled water. The plating bath composition comprises exactly $1 \mathrm{mM}$ of $\mathrm{H}_{2} \mathrm{PtCl}_{6}, 13 \mathrm{~g}$ of citric acid, and $0.25 \mathrm{M} \mathrm{H}_{2} \mathrm{SO}_{4}$ and the overall electrolyte adjusted to $500 \mathrm{~mL}$. The platinum nanoparticle was effectively deposited on carbon substrate at various current densities such as 1.5, 3, 6, 9, and $15 \mathrm{~mA} \mathrm{~cm}^{-2}$ for $600 \mathrm{~s}$. Prior to Pt deposition, the carbon paper was electrochemically activated by applying $-5 \mathrm{~mA} \mathrm{~cm}^{-2}$ for $20 \mathrm{~s}$ in $0.5 \mathrm{M}$ of $\mathrm{H}_{2} \mathrm{SO}_{4}$. Finally, the deposited substrate material was repeatedly rinsed with distilled water, followed by drying at $80{ }^{\circ} \mathrm{C}$ for $3 \mathrm{~h}$.

\subsection{Materials Characterization}

Elemental composition and surface morphology were examined by field emission scanning electron microscopy (FE-SEM) on a TESCAN MIRA 3 (Brno, Czech Republic) instrument attached to dispersive $\mathrm{X}$-ray spectrometry at an operating voltage from 8 to $15 \mathrm{kV}$. Overall, microstructural images were obtained by high-resolution transmission electron microscopy (HR-TEM, Talos F200S, Thermo Fisher Scientific, Eindhoven, The Nether- 
lands). Powder X-ray diffraction (XRD) measurements were performed on a BRUKERbinary V3 powder diffractometer with $\mathrm{Cu} \mathrm{K}_{\alpha}$ radiation. Chemical oxidation states of the electrodeposited $\mathrm{Pt}$ were studied by X-ray photoelectron spectroscopy (XPS-Omicron nanotechnologies Instrument, $\mathrm{GmbH}$, Taunusstein, Germany).

\section{Results and Discussion}

3.1. Pt Particle Electrochemically Deposited on A Carbon Substrate and Their Response to Varying Current Density

Figure 1a-c shows the FE-SEM micrographs of Pt particles deposited at different current densities on the carbon substrate. It is clear from the low-magnification FE-SEM micrographs that the Pt particles are uniformly electrodeposited/grown on the carbon substrate under the chronopotentiometry electrodeposition condition current limits of 1.5, 6 , and $15 \mathrm{~mA} \mathrm{~cm}^{-2}$, respectively. It is noteworthy that the platinum metal deposition was performed at room temperature, maintaining a bath $\mathrm{pH}$ of 1 at a stirring rate of $\sim 800 \mathrm{rpm}$ and a deposition time of $600 \mathrm{~s}$, which were kept constant for all the samples. The highmagnification FE-SEM image of Figure 1d indicates the formation of a well-defined $\mathrm{Pt}$ sphere with an applied minimum current density of $1.5 \mathrm{~mA} \mathrm{~cm}^{-2}$. Over 150 particles confirm the shape distribution in the FE-SEM images, which appears to be a sphere. The above result suggests the effectiveness of using lower current density to control the shape of $\mathrm{Pt}$ and the formation of spheres. However, the Pt particle size varied from 100 to $300 \mathrm{~nm}$ on the carbon surface, as can be observed more clearly in Figure 1d. The particle size variation attributed to the self-limiting growth mechanism of $\mathrm{Pt}$ to a maximum to $300 \mathrm{~nm}$, above which the Pt nucleation/growth happens on an adjacent site. As the current density limit increased from 1.5 to 3 and $6 \mathrm{~mA} \mathrm{~cm}^{-2}$, the sphere-shaped Pt nanoparticles slowly start to form a flower morphology $\left(3 \mathrm{~mA} \mathrm{~cm}{ }^{-2}\right)$, as given in Figure S1. Comparatively increasing the current density to $6 \mathrm{~mA} \mathrm{~cm}^{-2}$, the above mixed Pt morphology entirely changed and formed flower with petals to look like a rose flower shape on a carbon substrate, as shown in Figure 1e. The experiment performed with a higher current density of 9 (Figure S1) and $15 \mathrm{~mA} \mathrm{~cm}^{-2}$ resulted in a homogeneous distribution of sharp petals with a core-rose flower shape from Figure 1f. It is clear from the above results that an increase in applied current density during electrodeposition results in an increasing growth process with more dendritic structures grown over the existing shapes.

Figure $1 \mathrm{~g}$ shows the TEM micrograph of the Pt particles deposited at a current density of $1.5 \mathrm{~mA} \mathrm{~cm}{ }^{-2}$, clearly indicating spherical morphology. This observation is in good agreement with the FE-SEM micrographs. These spherical Pt nanoparticles are found to be of high crystallinity and are formed by the group of smaller nanospheres with a size range of 1-3 nm. Relatively increasing Pt deposition current to $6 \mathrm{~mA} \mathrm{~cm}^{-2}$ resulted in the change from globular nanosphere structure to dendritic flower-like shape, as observed from Figure 1h. A higher-magnification micrograph reveals individual Pt has an oval shape with nanocrystalline nature, which is visible from Figure 1i. Besides, while increasing Pt deposition current density to $15 \mathrm{~mA} \mathrm{~cm}^{-2}$, many Pt particles are formed. However, during the experiment, while increasing the current density to more than $15 \mathrm{~mA} \mathrm{~cm}{ }^{-2}$, the $\mathrm{Pt}$ deposition rate decreases on the carbon surface and form as crystal nature, and some $\mathrm{Pt}$ particle is found to be floating on the electrolyte. The chemical composition determined by Energy Dispersive X-RayAnalyzer (EDX) specifies that Pt particles are deposited on the carbon, and no other impurities are observed (Figure S2). 

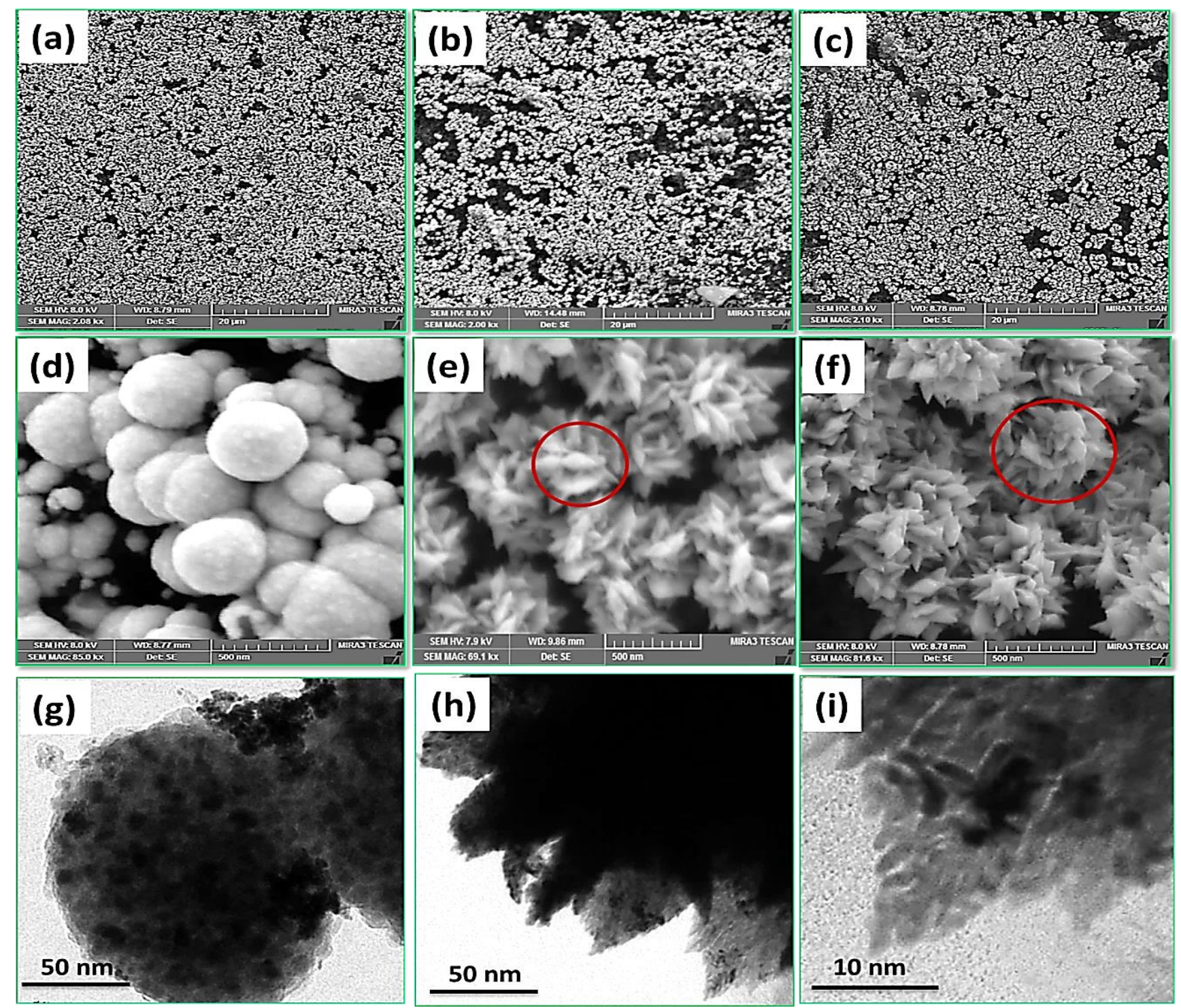

Figure 1. Low-magnification field emission scanning electron microscope (FE-SEM) micrographs (a-c) and high magnification $(\mathbf{d}-\mathbf{f})$ with various $\mathrm{Pt}$ deposition current densities of $1.5,6$, and $15 \mathrm{~mA} \mathrm{~cm}^{-2}$ and (g-i) high resolution transmission electron microscopy (HR-TEM) image with Pt deposition current densities of 1.5 and $6 \mathrm{~mA} \mathrm{~cm}^{-2}$. (e,f-circled region shows dentritic flower-like morphology)

The multi-segmented Pt crystal structure with different shapes synthesized over carbon electrodes is characterized by X-ray diffraction. Figure 2a shows that all samples have identical XRD profiles. The XRD pattern of Pt electrodeposited at different current densities indicates that the sphere and flower correspond to the face center cubic phase, which is in good agreement with JCPDS \# 87-0647. The peaks at $39.8^{\circ}, 46.2^{\circ}$, and $67.8^{\circ}$ attributes to the (111), (200), and (220) diffraction lines, which confirm that Pt is in the metallic state. In the present work, while increasing Pt deposition current density, the rate of Pt deposition on carbon surface and crystallinity also improved. The XRD results indicate that the growth formation and crystallinity increase with increasing Pt deposition current density. The expended region between $10^{\circ}$ and $30^{\circ}$ is given in Figure 2a inset. The sharp peak at $18.1^{\circ}$ and $26.4^{\circ}$ corresponds to (100) and (002) facets of PTFE and graphitic carbon observed from carbon substrate and consistently reflected for all samples. 

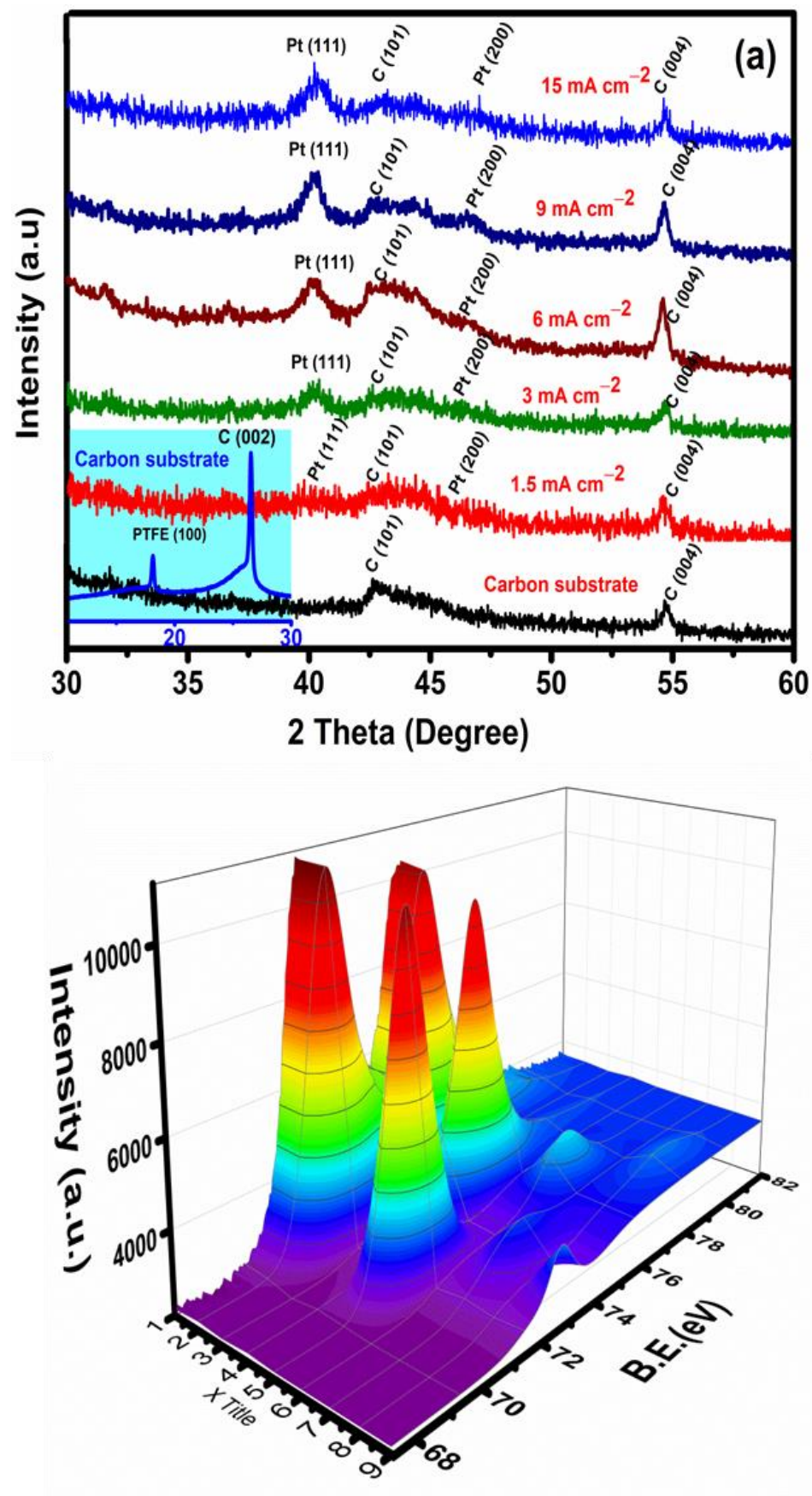

Figure 2. (a) Typical X-ray diffraction (XRD) pattern with Pt deposition of different current densities on a carbon substrate. (Note: The expended region between $10^{\circ}$ and $30^{\circ}$ indicated two different peaks due to carbon and PTFE observed for all samples). (b) 3D view XPS spectrum of Pt 4f binding energy orbital.

Furthermore, to analyze/examine Pt nanoparticles surface oxidation states, XPS studies were conducted. XPS survey spectrum for Pt deposited on carbon substrate at a current density of $6 \mathrm{~mA} \mathrm{~cm}^{-2}$ is shown in Figure S3, which reveal predominant peaks of oxygen, carbon and platinum, and no other impurities are detected. Moreover, the de-convoluted Pt $4 \mathrm{f}$ peak in Figure $2 \mathrm{~b}$ shows three doublet binding energy peaks. The Pt $4 \mathrm{f}$ core level has a sharp peak at 71.2 and $74.5 \mathrm{eV}$, which is associated with $\mathrm{Pt} 4 \mathrm{f} 7 / 2$ and $4 \mathrm{f}$ $5 / 2$, representing that $\mathrm{Pt}$ has a highly metallic state. Similarly, an interim and minor peak at 72.4 and $76.3 \mathrm{eV}$ and 73.4 and $78.2 \mathrm{eV}$ predicted $\mathrm{Pt}$ to be in $(+2)$ and $(+4)$ oxidation states. 


\subsection{Influence of Time on Pt Particle Deposited on the Carbon Substrate}

Figure 3 shows FE-SEM images of Pt materials grown onto a carbon substrate by electrochemical deposition route in relation to time. For this specific purpose, the current density was kept at $6 \mathrm{~mA} \mathrm{~cm}{ }^{-2}$, the temperature of $28^{\circ} \mathrm{C}$, and $\mathrm{pH}$ of 1 maintained at a stirring rate of $\sim 800 \mathrm{rpm}$. All these parameters were kept constant with time as the variable, and the $\mathrm{Pt}$ flower morphological parameters comprising the deposition rate and growth formation were investigated. It can be observed that all Pt film appeared of distinctive dendritic nature with a flower shape grown perpendicularly on a carbon substrate. The lower magnification images show that the deposition rate strongly increases with increasing deposition time. Pt structures almost covered the entire carbon substrate due to increased deposition duration from 300, 600, and $900 \mathrm{~s}$.
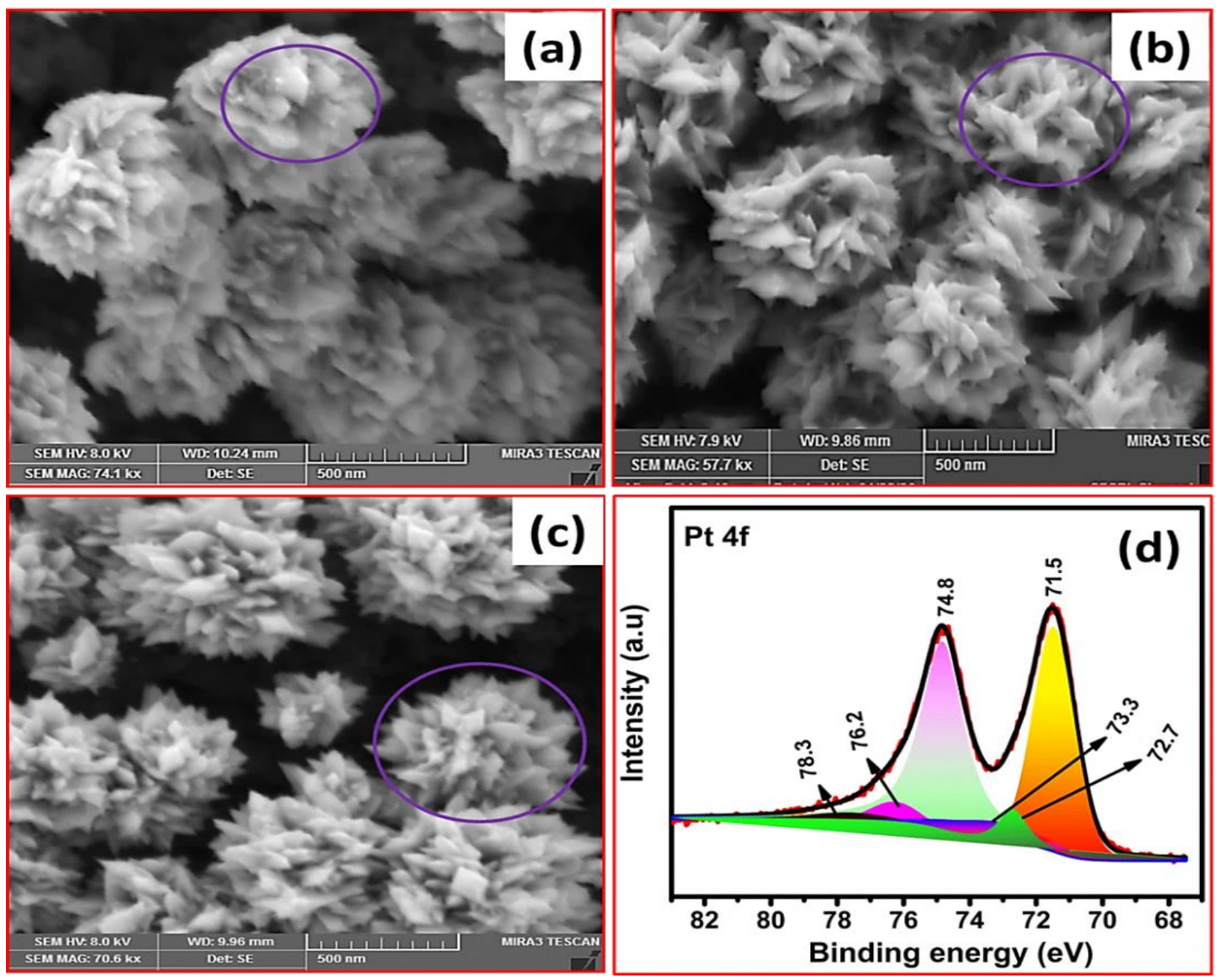

Figure 3. (a-c) FE-SEM micrographs for Pt structure deposited on a carbon substrate with the effect of time (300,600, and $900 \mathrm{~s})$ and (d) XPS spectrum of Pt $4 \mathrm{f}$ binding energy orbital with the effect of $900 \mathrm{~s}$. (a-c-circled region shows flower-like morphology)

Figure 3a reveals during Pt deposition for $300 \mathrm{~s}$, and it can be seen that Pt flower bud growth starts and petals are open slightly. Similarly, with increasing Pt deposition time of $600 \mathrm{~s}$, Pt flower grown on carbon surface and petals are more distinctively visible, as shown in Figure 3b. While increasing deposition time to $900 \mathrm{~s}$, more petals continue to grow on the substrate and show a sharp core-flower shape. It can be observed that the length-growth rate and petals formation intensely increase from 300 to $900 \mathrm{~s}$ duration time. Figure 3d shows XPS spectra of electrodeposited Pt on carbon substrate for the duration 
of $900 \mathrm{~s}$. The de-convoluted XPS spectra of $\mathrm{Pt} 4 \mathrm{f}$ binding energy peaks reveal that $\mathrm{Pt}$ has a metallic state acceding with different literature reports $[2,18,26]$. Similarly, XRD results also indicate that $\mathrm{Pt}$ has a face-center-cubic with the metallic state, as shown in Figure S4.

\subsection{Effect of Temperature on Pt Structure Fabricated on a Carbon Substrate}

The effect of temperature substantially affects the appearance of surface morphology and crystallinity of the deposited metal nanoparticles. To analyze the precise effect of temperature, all other electrodeposition parameters were kept constant. During the $\mathrm{Pt}$ deposition process, a current density of $6 \mathrm{~mA} \mathrm{~cm}^{-2}$, deposition time of $600 \mathrm{~s}$, bath $\mathrm{pH}$ of 1 , and stirring rate of $\sim 800 \mathrm{rpm}$ was maintained for all the temperatures. Figure 4 displays the FE-SEM images of $\mathrm{Pt}$ grown on a carbon substrate with varying bath temperatures. In the present work, bath temperature is increased from room temperature to $80{ }^{\circ} \mathrm{C}$. $\mathrm{Pt}$ deposited at room temperature reveal a rose-flower shape, and petals are more distinctively visible/open, as shown in Figure 4a. However, while increasing the bath temperature to $50{ }^{\circ} \mathrm{C}$, a change of the Pt petals morphology to rods is observed from Figure $4 \mathrm{~b}$. Further increase in electrolyte bath temperature to $80{ }^{\circ} \mathrm{C}$ resulted in increased Pt rods size with sharp crystal growth, as shown in Figure 4c. The increased electrolyte bath temperature is believed to decrease the electrolyte viscosity, thereby replenishing the double layer quite faster [27]. It also increases solubility, leading to increased electrolyte conductivity resulting in the growth process gradually. According to Sunil Kumar et al. the deposition process at a high-bath temperature usually decreases the adsorption of hydrogen on the deposits and reduces stress [28].

Further, the HR-TEM image reveals that Pt has a nanorod shape with sharp edges and rough surface, observed in Pt deposited on a carbon substrate at a temperature of $80^{\circ} \mathrm{C}$, as shown in Figure $4 \mathrm{~d}$. In addition to that, an increase in bath temperature from room temperature to $80^{\circ} \mathrm{C}$ resulted in increased grain size of Pt metal particles as observed from XRD measurement (Figure 4e). Moreover, XPS of Pt deposited at a temperature of $80^{\circ} \mathrm{C}$ also clearly reveals that $\mathrm{Pt}$ is in a metallic state (Figure $4 \mathrm{f}$ ).

The above results indicate that the formulated electrolyte ion present has a certain zigzag Brownian motion at room temperature. This random motion of ions may collide with other ions, resulting in ionic direction changes in an applied electric field. At room temperature and an applied current density of $6 \mathrm{~mA} \mathrm{~cm}^{-2}$, the cell voltage was low in the initial stage $(1.8 \mathrm{~V})$ and started increasing at a quite faster rate $(2.2 \mathrm{~V})$ during the initial $50 \mathrm{~s}$, and once Pt metal on a carbon substrate was saturated, the decrement in voltage was relatively slow $(2.1 \mathrm{~V})$. The reason is that Pt growth continues faster at the initial stage on carbon substrate and petals are more open during the optimum time and temperature, which is in good agreement with the effect of time study as given in Figure 3a. Further, the electrodeposition was studied at $50^{\circ} \mathrm{C}$, and the electrodeposition was commenced as discussed above, and the applied current density $\left(6 \mathrm{~mA} \mathrm{~cm}^{-2}\right)$ was maintained.

As discussed earlier, during Pt deposition at room temperature, the initial voltage was high and started to decrease gradually with time. However, at $50^{\circ} \mathrm{C}$, the initial voltage is higher in the initial stage $(1.82 \mathrm{~V})$ and a bit lower after $100 \mathrm{~s}(1.7 \mathrm{~V})$ and slowly saturated, however the overall voltage lesser than the room temperature experiment. The reason may be, at a higher temperature, there is more Brownian motion in the formulated electrolyte, and the formation of branches change look like a rod shape and deposition also enhanced as compared to room temperature. Experiments carried out for Pt deposition at $80^{\circ} \mathrm{C}$ also exhibit almost similar trends and the tendency of reducing cell voltage of $1.56 \mathrm{~V}$. It is clear from the FE-SEM micrographs of electrodeposited $\mathrm{Pt}$ at a higher temperature that growth patterns are highly dense compared to that of Pt electrodeposited at a lower temperature, as shown in Figure 4c. In addition, the branch size also increased with relatively thicker and wider stems, as evident from the FE-SEM micrographs. This may be due to increased bath temperature; the Influence of the ions random Brownian motion has increased, resulting in thicker branches and denser Pt deposit. 

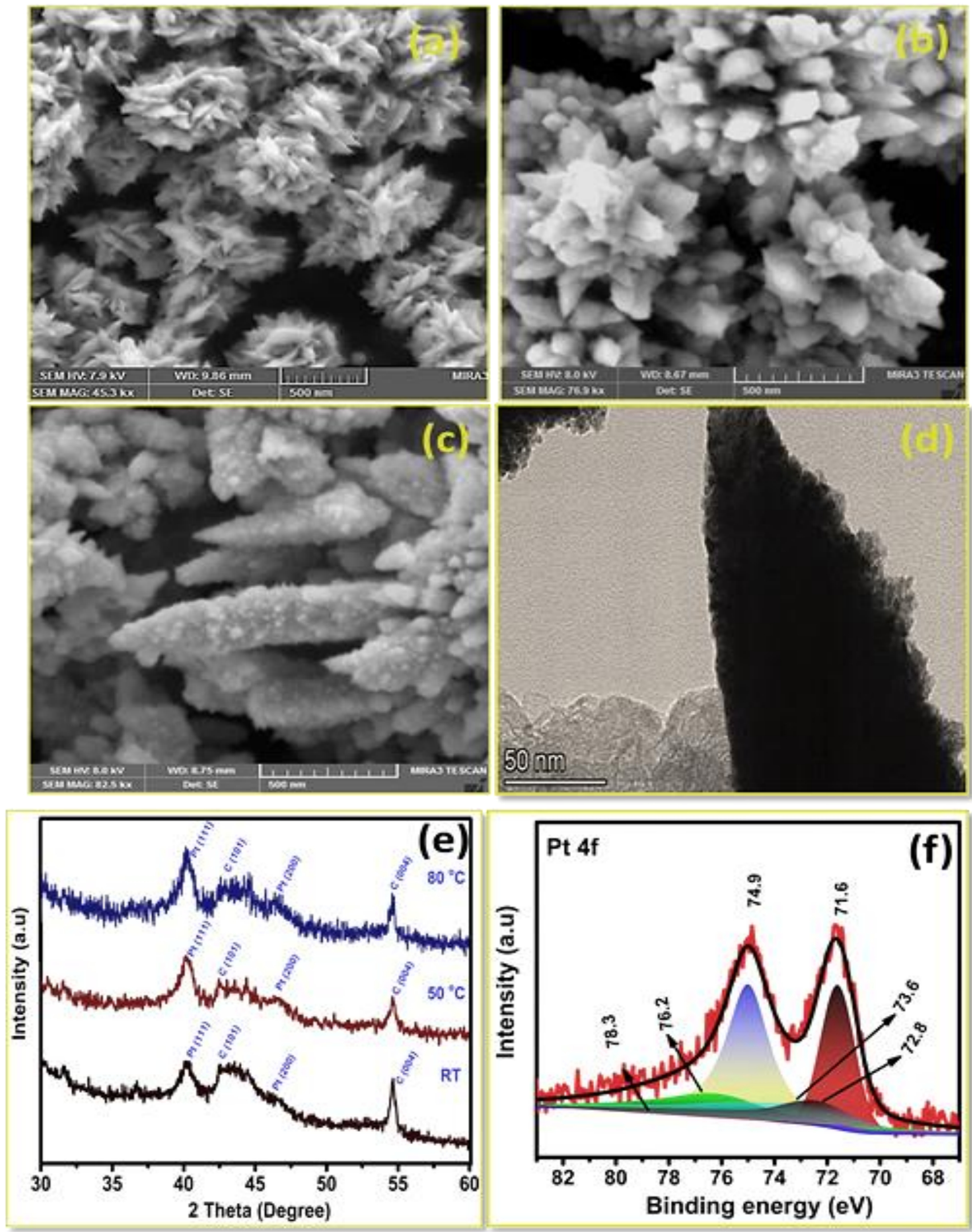

Figure 4. FE-SEM micrographs of Pt deposited on carbon substrate with effect of bath temperature; (a) room temperature, (b) $50^{\circ} \mathrm{C}$, (c) $80^{\circ} \mathrm{C}$, (d) HR-TEM image of Pt deposition $\left(80^{\circ} \mathrm{C}\right)$, (e) XRD pattern, and (f) XPS Pt $4 \mathrm{f}$ spectrum of Pt deposition at $\left(80^{\circ} \mathrm{C}\right)$. 
During Pt deposition at room temperature, Pt grows into distinct branches, and the formation of the rose flower shape is seen. While increasing bath temperature to $50{ }^{\circ} \mathrm{C}$, branches tend to grow faster at the later stage. Further, the surface morphology's overall appearance diverges from the one obtained at room temperature, where the rods were formed and more of an open structure. In addition, while increasing the temperature to $80{ }^{\circ} \mathrm{C}$, it appeared that surface morphology had become relatively thicker, with a rough surface and sharp edges visible, as seen from Figure $4 c, d$, compared to low temperature (Figure $4 \mathrm{~b}$ ). This formation is due to increasing Brownian motion of higher magnitude at a higher temperature, leading to an excess of agitation and thermal drifting of ions in the electrolytic solution.

\subsection{Pt Structure on A Carbon Substrate with the Influence of $\mathrm{pH}$}

The Pt particle deposition and growth kinetics during electrochemical deposition from electrolytes of different $\mathrm{pH}$ and overall mass rates are alleged to play a specifically important role in forming different shapes. Figure 5a-d shows the surface morphology of Pt metal particle electrodeposited at different electrolyte $\mathrm{pH}$. For this study, deposition parameters other than $\mathrm{pH}$ were kept constant in all cases, viz., the current density $\left(6 \mathrm{~mA} \mathrm{~cm}^{-2}\right)$, bath kept at temperature, deposition time of $600 \mathrm{~s}$ and stirring rate of $\sim 800 \mathrm{rpm}$ was maintained.
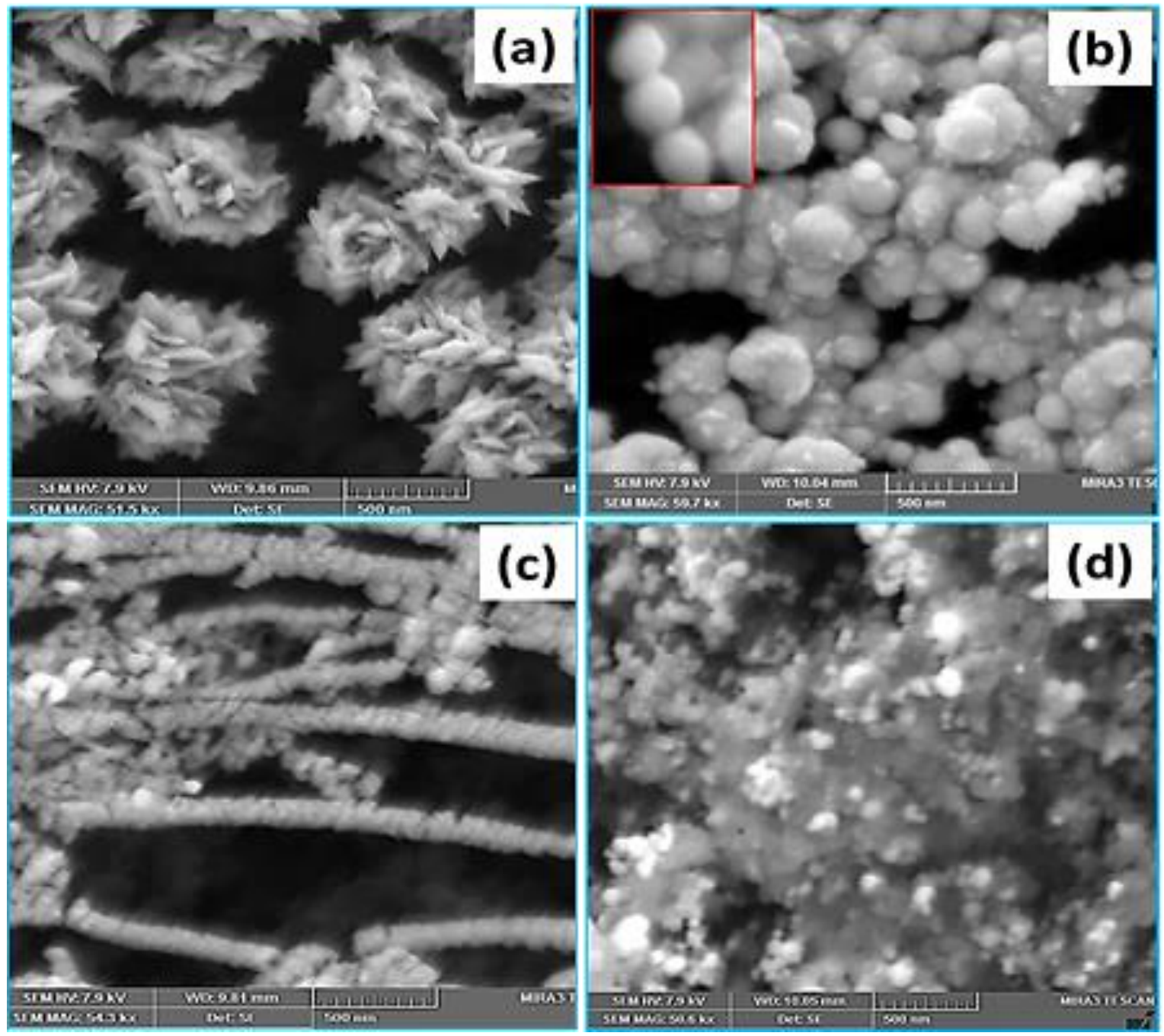

Figure 5. FE-SEM images of Pt deposited with influence of $\mathrm{pH}$ : (a) $\mathrm{pH} 1$, (b) $\mathrm{pH}$ 3, (c) pH 7, and (d) $\mathrm{pH}$ 10. (b-inset shows pellet-shaped globular morphology of deposited $\mathrm{Pt}$ ) 
FE-SEM micrographs in Figure 5a for electrodeposited Pt at a lower $\mathrm{pH}$ of formulated electrolyte reveals flower-like (rose) morphology of Pt. The Pt metal films are very thin, mainly caused by the high hydrogen evolution during electrodeposition at low $\mathrm{pH}$ values with respect to current density. With increasing the $\mathrm{pH}$ to value 3 , the Pt film's overall surface is observed to be smooth and uniform compared to lower $\mathrm{pH}$, which may be due to a smaller amount of hydrogen evolution while increasing $\mathrm{pH}$. Similarly, the surface shape also changes from flower morphology to pellet shape, which is observed from Figure $5 \mathrm{~b}$. The Pt film's surface significantly increased by increasing formulated $\mathrm{pH}$ up to 7 using $\mathrm{NaOH}$, resulting in the chain-like shape, as shown in Figure 5c. Further, when the $\mathrm{pH}$ is increased to 10, metal hydroxides such as $\mathrm{PtOH}$ form and begin precipitating in the electrolyte. The surface morphology changed and formed the agglomeration/Nodular structure of $\mathrm{Pt}$. In addition to that, a higher $\mathrm{pH}$ of formulated electrolytes favors the formation and absorption of metal hydroxides and depresses the freshly deposited Pt metal. The electrochemical deposition curves indicating the Influence of current density, time, temperature, and $\mathrm{pH}$ for Pt deposition on carbon are given in Figure 6. The change of Pt morphology in relation to these parameters is discussed in detail above.

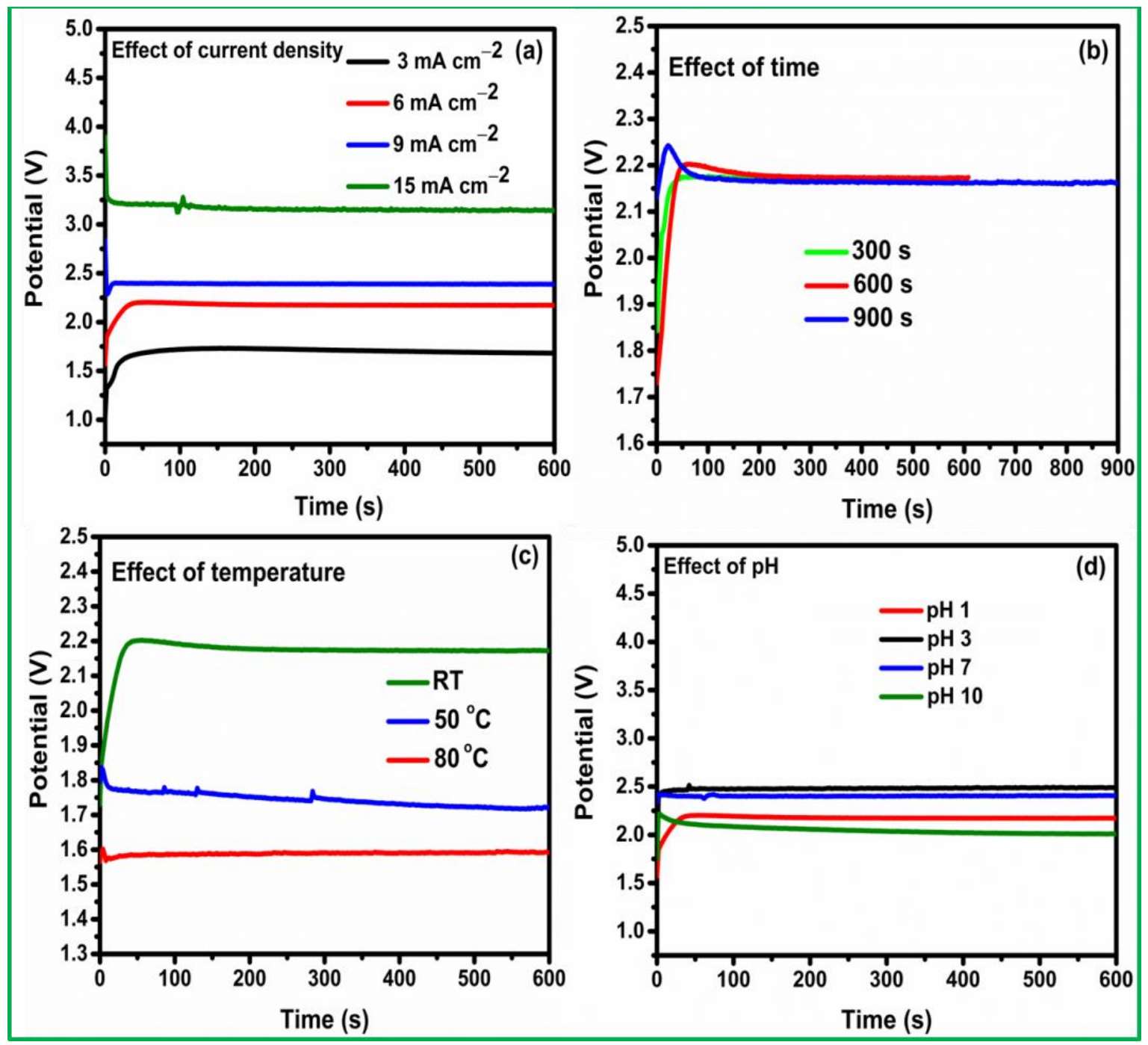

Figure 6. Pt deposition on a carbon surface via the (a) effect of current density, (b) effect of time (constant current density), (c) effect of temperature, and (d) effect of $\mathrm{pH}$ with constant current density $\left(6 \mathrm{~mA} \mathrm{~cm}^{-2}\right)$. 
An optimized electrode obtained via electrochemical deposition was subjected to realtime PEFC testing for its durability. The electrochemically deposited Pt on carbon obtained with the applied current density of $6 \mathrm{~mA} \mathrm{~cm}^{-2}$ was used as an anode with metal loading of $18 \mu \mathrm{g} \mathrm{cm}{ }^{-2}$, and commercially available $\mathrm{Pt} / \mathrm{C}$ metal loading of $50 \mu \mathrm{g} \mathrm{cm}^{-2}$ was used as a cathode. (Note: An optimum amount of $40 \mathrm{wt} \%$ of commercial $\mathrm{Pt} / \mathrm{C}$ was wet with deionized water followed by the addition of $5 \mathrm{wt} \%$ of Nafion ionomer and IPA solution and then sonicated for $45 \mathrm{~min}$. The above admixture was coated on GDL (DC-35 commercially available carbon electrode). For comparative studies, commercially available $\mathrm{Pt} / \mathrm{C}$ was used as an anode (50 $\left.\mu \mathrm{g} \mathrm{cm}^{-2} \mathrm{Pt}\right)$ and a cathode $\left(50 \mu \mathrm{g} \mathrm{cm}^{-2}\right)$, respectively. Nafion-HP membrane was then placed between the above two electrodes to design a membrane electrode assembly (MEA) by hot-press with a compaction pressure of $20 \mathrm{~kg} \mathrm{~cm}^{-2}$ for $2 \mathrm{~min}$. PEFC test was performed in a cell fixture of $25 \mathrm{~cm}^{2}$ (Fuel cell technologies). The steady-state performance and stability test was carried out under the dry gas condition with an operating temperature of $40^{\circ} \mathrm{C}$ using Birode Instruments.

Figure 7a shows steady-state data for $\mathrm{Pt} / \mathrm{C}$ and $\mathrm{Pt}$ particle electrochemically deposited on carbon. Pt deposited on carbon with an optimum current density of $6 \mathrm{~mA} \mathrm{~cm}^{-2}$ shows a superior current density of $560 \mathrm{~mA} \mathrm{~cm}^{-2}$ at $0.4 \mathrm{~V}$ on par with the commercial $\mathrm{Pt} / \mathrm{C}$. Similarly, Figure $7 \mathrm{~b}, \mathrm{c}$, shows $\mathrm{Pt}$ deposition on carbon $\left(6 \mathrm{~mA} \mathrm{~cm}^{-2}\right)$ and $\mathrm{Pt} / \mathrm{C}$ have better $\mathrm{H}_{2}$ adsorption and desorption behaviour. Similarly, under dry gas operating condition, $\mathrm{Pt}$ deposited on carbon shows higher stability of $550 \mathrm{~mA} \mathrm{~cm}^{-2}$ at $0.4 \mathrm{~V}$ even after $1200 \mathrm{~min}$, as shown in Figure $7 \mathrm{~d}$. Ye et al. prepared PtRuIr nanoclusters by selectively pulsing electrodeposition method and reported that the optimum concentration of Ir in the PtRu bifunctional electrocatalyst resulted in a higher current density of $150 \mathrm{~mA} \mathrm{~cm}{ }^{2}$ at $0.4 \mathrm{~V}$ under humidified $\mathrm{H}_{2}: \mathrm{O}_{2}$ configuration [29].

Similarly, Yang et al. prepared PtNi alloy octahedral nanoparticles electrochemically deposited on carbon substrate via pulse-like hydrothermal method. The authors reported that the effect of temperature on the pulse deposition method could result in speeding up the growth process, and the final Pt-Ni alloy morphology was observed to be different due to the different growth times and temperatures. Besides, during oxygen reduction reaction Pt-Ni octahedral alloy exhibited a $50 \mathrm{mV}$ positive shift of the half-wave potential compared to commercial $\mathrm{Pt} / \mathrm{C}$ [30]. In addition, Liu et al. group also studied the mechanism and kinetic study of the pulse electrodeposition process of Pt on carbon. During pulse current electrodeposition, larger current densities are suitable for the $\mathrm{Pt}$ deposition process, which may be leading to larger cathode overpotentials, resulting in increased nucleation rate and beneficial to form smaller Pt metal particles. Similarly, introducing proper additives is also useful for forming various morphology and improving fuel cell performance progressively [31,32].

The present work reveals that the direct current deposition process with lower metal loading of Pt deposited on carbon shows superior fuel cell performance and the peak power density of $250 \mathrm{~mW} \mathrm{~cm} \mathrm{~cm}^{-2}$ at $0.4 \mathrm{~V}$. Moreover, during dry gas operation, it shows higher stability of $550 \mathrm{~mA} \mathrm{~cm}^{-2}$ at $0.4 \mathrm{~V}$ even after $1200 \mathrm{~min}$. While initial fuel cell studies with the electrochemically deposited $\mathrm{Pt}$ on carbon are promising, the other important parameter for the $\mathrm{Pt}$ morphology with time, temperature, and $\mathrm{pH}$ as anode and cathode electrocatalyst needs to be studied in detail. Further studies are in progress. 


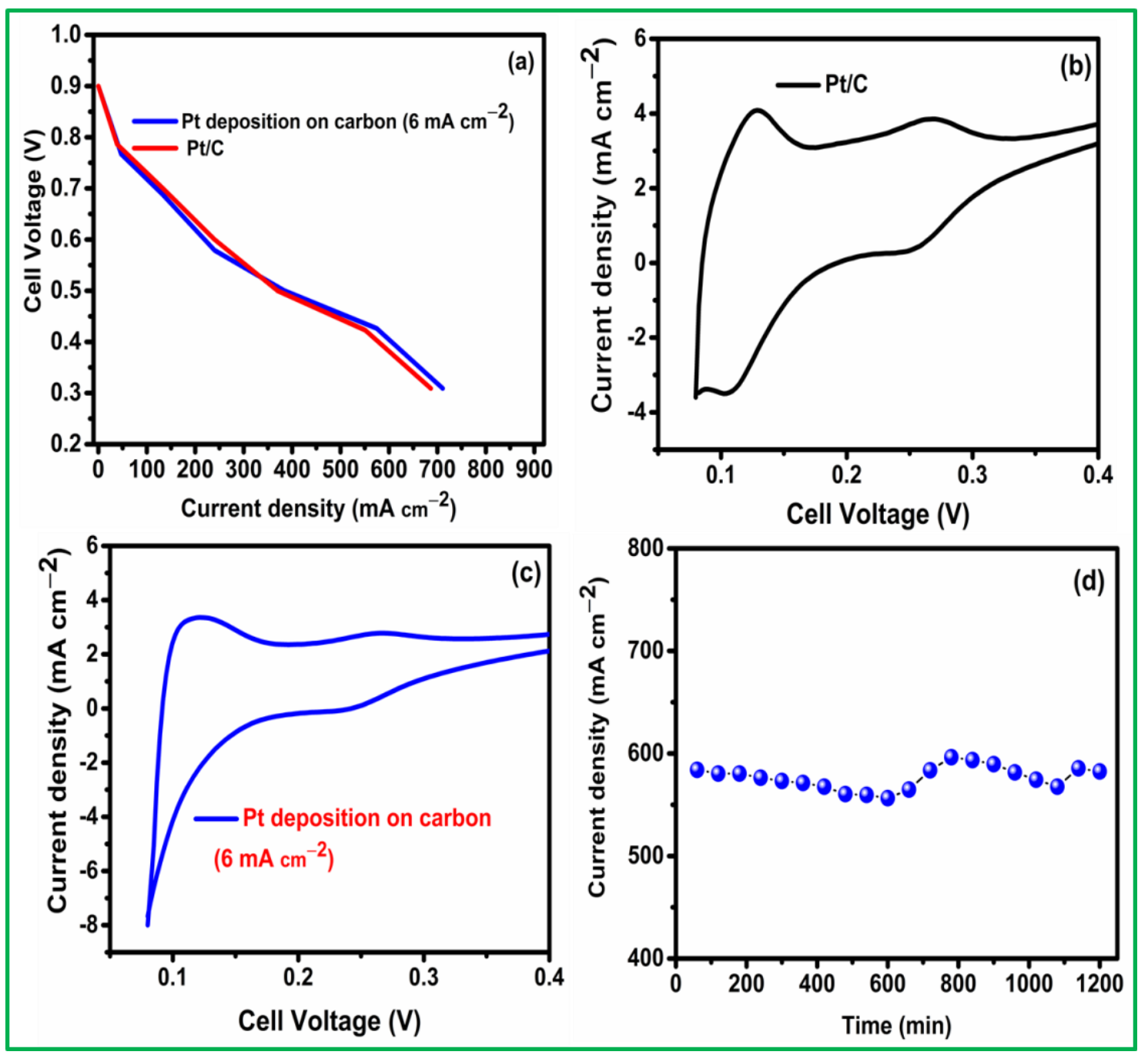

Figure 7. (a) Fuel cell performance, $(\mathbf{b}, \mathbf{c}) \mathrm{H}_{2}$ adsorption and desorption behaviour of $\mathrm{Pt} / \mathrm{C}$ and $\mathrm{Pt}$ deposited on carbon $\left(6 \mathrm{~mA} \mathrm{~cm}^{-2)}\right.$, and (d) stability test at $0.4 \mathrm{~V}$ for Pt deposited on carbon $\left(6 \mathrm{~mA} \mathrm{~cm}^{-2}\right)$.

\section{Conclusions}

In conclusion, different shapes of surface morphologies of Pt metal particles are fabricated by a one-step electrochemical approach. The applied current density is the most critical factor to change the surface morphology from sphere to core-rose flower shape with a desired size and crystallinity growth. The formation of the $\mathrm{Pt}$ flower growth mechanism was also successfully investigated at varying times. In addition, instantaneous nucleation was found by varying temperature and $\mathrm{pH}$ to have a significant impact on surface morphology and crystallinity. Electrochemically deposited Pt on carbon substrate with optimum current density shows excellent fuel cell stability under dry gas condition. The above results reveal that electrochemical deposition of Pt materials with different morphology opens a wide application in sustainable energy.

Supplementary Materials: The following are available online at https:/ /www.mdpi.com/article/10 $.3390 / \mathrm{ma14092330/s1}$, Figure S1. FE-SEM image for Pt deposition on carbon substrate with a current density of 3 and $9 \mathrm{~mA} \mathrm{~cm}{ }^{-2}$, Figure S2. EDX measurement of Pt nanoparticles is deposited on a carbon substrate with different current density, Figure S3. XPS survey spectrum for Pt deposited on a carbon substrate at a current density of $6 \mathrm{~mA} \mathrm{~cm}^{-2}$, Figure S4. XRD pattern with Influence of time on Pt nanoparticle deposited on carbon substrate. 
Author Contributions: Methodology, S.R.; writing original draft, formal analysis and validation, P.D.; data curation and editing, S.V.S.; Investigation, supervision, review and editing, S.D.B. All authors have read and agreed to the published version of the manuscript.

Funding: Dhanasekaran and S. Vinod Selvaganesh thank CSIR-for Senior Research Associateship (Scientist's Pool Scheme-9123-A and 9178-A, respectively), and S.D. Bhat thanks the Department of Science and Technology major DST-HFC Grant DST-GAP-28/19 (TMD/HFC/2K18/78(G)/1) for the financial support

Institutional Review Board Statement: CSIR-CECRI contribution number CECRI/PESVC/Pubs./ 2021-019.

Informed Consent Statement: Not applicable.

Data Availability Statement: Data sharing not available.

Acknowledgments: We thank S. Mohan, Chief Scientist (Retd.) CSIR-CECRI Madras unit for his valuable support.

Conflicts of Interest: The authors declare no conflict of interest.

\section{References}

1. Bing, Y.; Liu, H.; Zhang, L.; Ghosh, D.; Zhang, J.J. Nanostructured Pt-alloy electrocatalysts for PEM fuel cell oxygen reduction reaction. Chem. Soc. Rev. 2010, 39, 2184-2202. [CrossRef]

2. Dhanasekaran, P.; Shukla, A.; Vinod Selvaganesh, S.; Mohan, S.; Bhat, S.D. Silica-decorated carbon-Pt electrocatalyst synthesis via single-step polyol method for superior polymer electrolyte fuel cell performance, durability and stack operation under low relative humidity. J. Power Sources 2019, 438, 226999. [CrossRef]

3. Zhong, C.; Hu, W.B.; Cheng, Y.F. Recent advances in electrocatalysts for electro-oxidation of ammonia. J. Mater. Chem. A 2013, 1, 3216-3238. [CrossRef]

4. $\quad \mathrm{Wu}, \mathrm{S} . ; \mathrm{Liu}, \mathrm{J}$.; Tian, J.Z.; Cai, Y.; Ye, Y.; Yuan, Q.; Liang, C. Highly dispersed ultrafine Pt nanoparticles on reduced graphene oxide nanosheets: In situ sacrificial template synthesis and superior electrocatalytic performance for methanol oxidation. ACS Appl. Mater. Interfaces 2015, 7, 22935-22940. [CrossRef] [PubMed]

5. Duan, Y.; Sun, Y.; Pan, S.; Dai, Y.; Hao, L.; Zou, J. Self-stable WP/C support with excellent co-catalytic functionality for Pt: Enhanced catalytic activity and durability for methanol electro-oxidation. ACS Appl. Mater. Interfaces 2016, 8, 33572-33582. [CrossRef] [PubMed]

6. Liu, J.; Zhong, C.; Du, X.; Wu, Y.; Xu, P.; Liu, J.; Hu, W. Pulsed electrodeposition of Pt particles on indium tin oxide substrates and their electrocatalytic properties for methanol oxidation. Electrochim. Acta 2013, 100, 164-170. [CrossRef]

7. Baingane, A.; Narayanan, J.S.; Slaughter, G. Sensitive electrochemical detection of glucose via a hybrid self-powered biosensing system. Sens. Bio-Sens. Res. 2018, 20, 41-46. [CrossRef]

8. Kocemba, I.; Rynkowski, J. The Influence of catalytic activity on the response of $\mathrm{Pt} / \mathrm{SnO}_{2}$ gas sensors to carbon monoxide and hydrogen. Sens. Actuators B Chem. 2011, 155, 659-666. [CrossRef]

9. Leite, L.; Benazzi, E.; George, N.M. Hydrocracking of phenanthrene over bifunctional Pt catalysts. Catal. Today 2001, 65, 241-247. [CrossRef]

10. Kariya, N.; Fukuoka, A.; Utagawa, T.; Sakuramoto, M.; Goto, Y.; Ichikawa, M. Efficient hydrogen production using cyclohexane and decalin by pulse-spray mode reactor with Pt catalysts. Appl. Catal. A Gen. 2003, 247, 247-259. [CrossRef]

11. Skander, M.; Retailleau, P.; Bourrie, B.; Schio, L.; Mailliet, P.; Marinetti, A. N-heterocyclic carbene-amine Pt(II) complexes, a new chemical space for the development of platinum-based anticancer drugs. J. Med. Chem. 2010, 53, 2146-2154. [CrossRef] [PubMed]

12. Gates, B.C. Supported metal clusters: Synthesis, structure, and catalysis. Chem. Rev. 1995, 95, 511-522. [CrossRef]

13. Dhanasekaran, P.; Vinod Selvaganesh, S.; Shukla, A.; Nagaraju, N.; Bhat, S.D. Boosting Pt oxygen reduction reaction activity and durability by carbon semi-coated titania nanorods for proton exchange membrane fuel cells. Electrochim. Acta 2018, 263, 596-609. [CrossRef]

14. Dhanasekaran, P.; Vinod Selvaganesh, S.; Bhat, S.D. Nitrogen and carbon doped titanium oxide as an alternative and durable electrocatalyst support in polymer electrolyte fuel cells. J. Power Sources 2016, 304, 360-372. [CrossRef]

15. Chen, G.; Yang, X.; Xie, Z.; Zhao, F.; Zhou, Z.; Yuan, Q. Hollow PtCu octahedral nanoalloys: Efficient bifunctional electrocatalysts towards oxygen reduction reaction and methanol oxidation reaction by regulating near-surface composition. J. Colloid. Interface Sci. 2020, 562, 244-251. [CrossRef]

16. Ahmadi, T.S.; Wang, Z.L.; Green, T.C.; Henglein, A.; El-Said, M.A. Shape-controlled synthesis of colloidal platinum nanoparticles. Science 1996, 272, 1924-1926. [CrossRef]

17. Ramirez, E.; Erades, L.; Philippot, K.; Lecante, P.; Chaudret, B. Shape control of platinum nanoparticles. Adv. Funct. Mater. 2007, 17, 2219-2228. [CrossRef] 
18. Dhanasekaran, P.; Vinod Selvaganesh, S.; Bhat, S.D. Enhanced catalytic activity and stability of copper and nitrogen doped titania nanorod supported Pt electrocatalyst for oxygen reduction reaction in polymer electrolyte fuel cells. New J. Chem. 2017, 41, 13012-13026. [CrossRef]

19. Paunovic, M. Electrochemical Deposition; Bard, A.J., Stratmann, M., Eds.; Wiley-VCH Verlag: Weinheim, Germany, 2007.

20. Paunovic, M.; Schlesinger, M. Fundamentals of Electrochemical Deposition, 2nd ed.; Wiley-Interscience: New York, NY, USA, 2006.

21. Dhanasekaran, P.; Lokesh, K.; Ojha, P.K.; Sahu, A.K.; Bhat, S.D.; Kalpana, D. Electrochemical deposition of three-dimensional platinum nanoflowers for high-performance polymer electrolyte fuel cells. J. Colloid. Interface Sci. 2020, 572, 198-206. [CrossRef]

22. Liu, J.; Fan, X.; Liu, X.; Song, Z.; Deng, Y.; Han, X.; Hu, W. Synthesis of cubic-shaped Pt particles with (100) preferential orientation by a quick, one-step and clean electrochemical method. ACS Appl. Mater. Interfaces 2017, 9, 18856-18864. [CrossRef]

23. Song, Y.J.; Kim, J.Y.; Park, K.W. Synthesis of Pd dendritic nanowires by electrochemical deposition. Cryst. Growt. Des. 2009, 9 , 505-507. [CrossRef]

24. Jia, F.; Wong, K.; Zhang, L. Electrochemical synthesis of nanostructured palladium of different morphology directly on gold substrate through a cyclic deposition/dissolution route. J. Phys. Chem. C 2009, 113, 7200-7206. [CrossRef]

25. Takai, A.; Yamauchi, Y.; Kuroda, K. Tailored electrochemical synthesis of 2D-hexagonal, lamellar, and cage-type mesostructured Pt thin films with extralarge periodicity. J. Am. Chem. Soc. 2010, 132, 208-214. [CrossRef] [PubMed]

26. Bharti, A.; Cheruvally, G. Influence of various carbon nano-forms as supports for Pt catalyst on proton exchange membrane fuel cell performance. J. Power Sources 2017, 360, 196-205. [CrossRef]

27. Sadiku-Agboola, O.; Sadiku, E.R.; Ojo, O.I.; Akanji, O.L.; Biotidara, O.F. Influence of operation parameters on metal deposition in bright nickel-plating process. Electrochim. Acta 2011, 29, 91. [CrossRef]

28. Kumar, S.; Pande, S.; Verma, P. Factor effecting electrodeposition process. Int. J. Curr. Eng. Technol. 2015, 5, 700-704.

29. Ye, F.; Xu, C.; Liu, G.; Li, J.; Wang, X.; Du, X.; Lee, J. A novel PtRuIr nanoclusters synthesized by selectively electrodepositing Ir on $\mathrm{PtRu}$ as highly active bifunctional electrocatalysts for oxygen evolution and reduction. Energy Convers. Manag. 2018, 155, 182-187. [CrossRef]

30. Yang, Z.; Wang, M.; Liu, G.; Chen, M.; Ye, F.; Zhang, W.; Yang, W.; Wang, X. Octahedral Pt-Ni nanoparticles prepared by pulse-like hydrothermal method for oxygen reduction reaction. Ionics 2020, 26, 293-300. [CrossRef]

31. Ye, F.; Wang, Z.; Xu, C.; Yuan, M.; Liu, P.; Yang, W.; Liu, G. Mechanism and kinetic study of pulse electrodeposition process of $\mathrm{Pt} / \mathrm{C}$ catalysts for fuel cells. Renew. Energy 2020, 145, 514-520. [CrossRef]

32. Ye, F.; Xu, C.; Liu, G.; Yuan, M.; Wang, Z.; Du, X. Effect of pulse electrodeposition parameters on electrocatalytic the activity of methanol oxidation and morphology of Pt/C catalyst for direct methanol fuel cells. Energy Convers. Manag. 2018, 160, 85-92. [CrossRef] 